\title{
An Observation of the Overwintering Aquatic Insects in a Prairie Pond in Saskatchewan, Canada
}

\author{
Jordan Edward Mihalicz*
}

\begin{abstract}
In temperate regions freshwater insects annually face the challenge of surviving the winter months or otherwise perishing. Ice formation presents a substantial danger to all life stages, from the eggs to adults. Accordingly, some species have adapted to overwinter within ice and emerge during the spring thaw. The diversity of aquatic species encased in the ice and frozen sediment of a prairie pond in Saskatchewan, Canada and their survival rate upon thawing was assessed in the winter of 2013. A total of 164 specimens were retrieved from the ice and sediment, 73 of which survived after thawing. Survival rate was greatest for Cymatia americana (Corixidae, Hemiptera) at 79.6\%. Corixids were found in distinct clusters encased in pond ice, a phenomenon not well documented in previous literature. A higher rate of survival was expected among the chironomids, although the value falls within ranges observed in previous studies. Additionally, members of other taxa including Notonectidae (Hemiptera), Haliplidae (Coleoptera), Ceratopogonidae (Diptera), and Coenagrionidae (Odonata) were recovered; however, these specimens exhibited much lower rates of survival.
\end{abstract}

Keywords: aquatic insects, Corixidae, entomology, overwintering, prairie potholes

\section{Introduction}

Insects have adapted to almost every habitat with the exception of marine environments. In temperate climates, the majority of insect species vanish at the onset of the winter months, returning in the spring. Where they go and how they survive the harsh temperatures has been the topic of many studies (Salt, 1961; Block, 1991; Moore and Lee, 1991; Irons et al., 1993; Strathdee and Bale, 1998; Sinclair et al., 2003; Danks, 2005, 2007a; Arrignon et al., 2007). Overwintering habits of both terrestrial and aquatic insects have been studied, although the former to a much greater extent (Moore and Lee, 1991). Indeed, many researchers believe that the habits of aquatic insects during the winter have been and continue to be a poorly studied subject (Irons et al., 1993; Danks, 2007a).

In the prairie province of Saskatchewan, Canada, winter temperatures are often below $-20^{\circ} \mathrm{C}$. For example, the mean monthly temperature for Saskatoon, Saskatchewan from December-March was $-16.9^{\circ} \mathrm{C}$ for the period 2000-2007 (Government of Canada, 2013). According to Government of Canada data from 2007, daily temperatures in February can fluctuate between $-13^{\circ} \mathrm{C}$ and $22^{\circ} \mathrm{C}$. During the winter months, most prairie ponds freeze over and a sheet of ice develops that sometimes extends into the benthic sediments. Some ponds freeze to the bottom, whereas others are large and/or deep enough to

\footnotetext{
*Department of Biology, College of Arts and Science, University of Saskatchewan, Saskatoon, SK, Canada
}

Correspondence: jem539@mail.usask.ca 
remain partially unfrozen. The diversity of insects in and around prairie ponds can be substantial during the summer months and can include members of the Coleoptera, Ephemeroptera, Hemiptera, Diptera, and Odonata (Irons et al., 1993). Diversity declines as the photoperiod becomes shorter and temperatures drop.

Freshwater insects that overwinter in water bodies face a broad set of challenges, including freezing, reduced oxygen levels, reduced food supply, and ice formation. It has been suggested that terrestrial insects must cope with harsher conditions as they are exposed to rapid fluctuations in temperature, while aquatic insects are buffered from sudden changes in temperature (Lencioni, 2004; Danks, 2008). Even so, aquatic insects may experience periods of hypoxia or anoxia during the winter, which contribute to the buildup of toxic substances such as hydrogen sulfide (Nagell, 1977b). Despite these challenges, aquatic insects have adapted in numerous behavioural and physiological aspects to cope with winter conditions.

In this study, the diversity of aquatic insects that overwinter in the frozen sediment and ice of a Saskatchewan prairie pond was examined. The objective of the present study was to determine which aquatic insects are able to survive being frozen during the winter. This was accomplished by retrieving ice samples from a small prairie pond. We found that several species survived.

\section{Materials and Methods}

\section{Sampling Techniques}

We decided that the most economical and effective method for this study was the use of a mallet and chisel. This experiment utilized a $2 \mathrm{~kg}$ mallet and a chisel with a $2.5 \mathrm{~cm}$ blade width.

\section{Study Site}

Aquatic insects were collected from a small prairie pond located approximately $6 \mathrm{~km}$ south of the city of Saskatoon, Saskatchewan (GPS coordinates N $52^{\circ} 03.346^{\prime}$ W $106^{\circ} 35.092^{\prime}$ ).

The pond completely freezes over during the winter, although it does not freeze to the bottom in the deeper areas, and measures approximately $80 \mathrm{~m}$ across at its widest point. We sampled ice and frozen sediment from February 16 to 17, 2013. Air temperature on the first day of sampling was approximately $2.0^{\circ} \mathrm{C}$ and $-15^{\circ} \mathrm{C}$ on the second day. Snow depth varied from approximately $0.4 \mathrm{~m}$ near the center of the pond to $0.7 \mathrm{~m}$ along the northern shore.

Overlying snow was cleared away before chiseling into the ice. The littoral sample was taken approximately $1 \mathrm{~m}$ from the shoreline and consisted of ice and frozen sediment. This sample was $0.2 \mathrm{~m}$ deep as measured from the surface of the ice and approximately $0.1 \mathrm{~m}$ wide. The other sample was taken approximately $4 \mathrm{~m}$ from the shoreline and consisted only of ice. An oval measuring $0.7 \mathrm{~m}$ in length, $0.5 \mathrm{~m}$ in width, and $0.25 \mathrm{~m}$ in depth was carved out of the ice. During this process, several corixids were discovered among the ice chips; these were included as part of the sample. The oval was slowly broken into smaller pieces from one side, which were then collected in a large bucket.

\section{Specimen Recovery}

We placed the ice and sediment samples in a refrigerator at $4^{\circ} \mathrm{C}$ until they had completely thawed. Thawing time was dependent on the size of each ice block; the samples were left for $12 \mathrm{~h}$ and checked every $2 \mathrm{~h}$. The water and sediment were then placed in separate white tubs. We removed the insects found in the thawed ice samples and placed them in a petri dish with pond water. Small quantities of sediment were placed in water from the thawed ice and were thoroughly searched for specimens.

Once removed, specimens were slowly warmed to room temperature and closely observed for signs of recovery. Specimens that did not exhibit indications of revival 4 hours after being freed from the ice were pronounced dead. We noted and preserved both live and dead specimens in separate vials containing 95\% ethanol. Examination was performed using a stereomicroscope. Specimens were identified using keys in Brooks and Kelton (1967) and Merritt et al (2008). Where possible, specimens were identified to species level.

\section{Results}

A total of 164 specimens were retrieved from the ice and sediment after thawing. Of these, 73 were found to be alive once warmed. A summary of the findings is presented in Table 1 . The corixids had the highest survival rate but it could have been higher due to unintentional maceration of some individuals during ice extraction. All of the corixids were identified as Cymatia americana and were found in deep ice samples except the lone Callicorixa audeni that was found in the sediment. The corixids were found 8 to $15 \mathrm{~cm}$ beneath the surface of the ice in distinct clusters ranging from 3 to $>10$ individuals (Figure 1 ).

Members of Chironomidae had a surprisingly low survival rate given the evidence of their resilience in many environments (Danks, 2007). Due to the difficulty in identifying chironomids beyond the family level and the variety of instars collected they were all grouped as Chironomidae in this study. The chironomids were found only in thawed sediment and the presence of hemoglobin was indicated by each specimen's bright to dark red colouration. Most were shriveled in appearance, and those that survived showed signs of lengthening after exposure to 
warmth. Many chironomids were found within cocoons built from their mucous secretions and surrounding organic material.

All damselfly naiads were found deep within the ice, near the bottom of the sample approximately $24 \mathrm{~cm}$ from the surface. These were identified as two possible genera (Enallagma and Coenagrion) but similarities between them made exact identification difficult.

Only a few specimens of other taxa were found in this study. Two Haliplus larvae were retrieved from the sediment; both were very small, approximately 2-3 mm, and were likely at an early instar stage. One Notonecta undulata was found in the deep ice samples and did not survive. Finally, four larval Ceratopogonidae were retrieved from the sediment, none of which survived. Two possible genera for these larvae were identified (Bezzia and Palpomyia), though neither could be confidently confirmed.

Figure 1: A photograph of a group of corixids frozen within one of the ice samples taken from a Saskatchewan prairie pond. Note the bubbles present around the group.

Figure 2: A photograph showing an aggregation of corixids in the ice of a pond in the St. Denis National Wildlife Area, Saskatchewan on April 2, 2012. The ice containing the corixids melted faster than the surrounding ice, possibly due to the dark colouration of the insects and the size of the group. Photo courtesy of Allen Maher, University of Saskatchewan

Table 1: A summary of the aquatic insects retrieved from ice and frozen sediment of a Saskatchewan prairie pond. Numbers of live and dead specimens are displayed. Survival rate for each taxon is shown. Where possible, identification was made to species level.
Figure 1

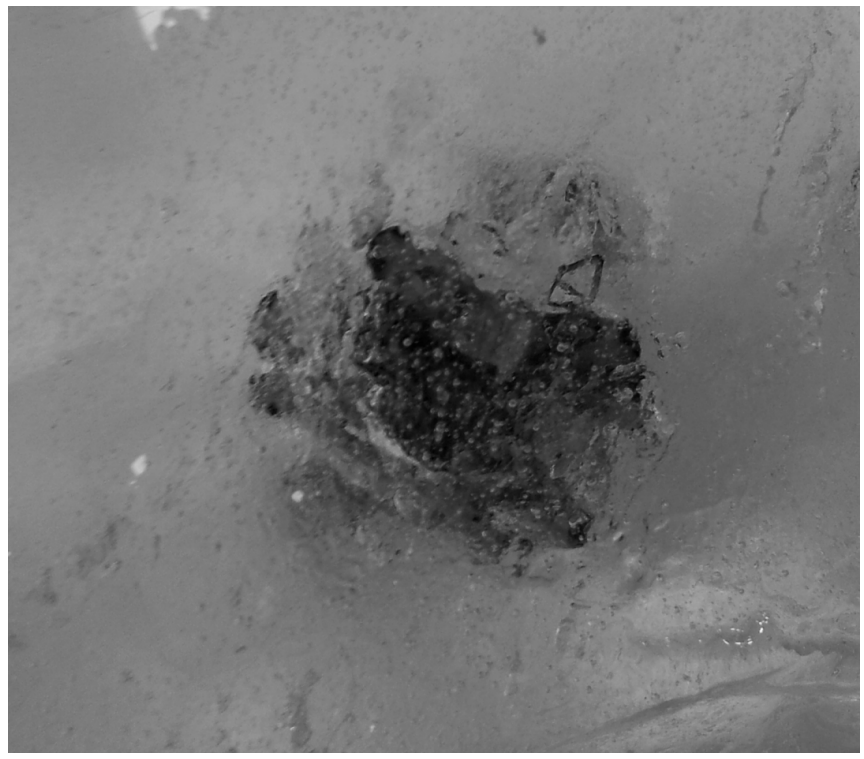

Figure 2

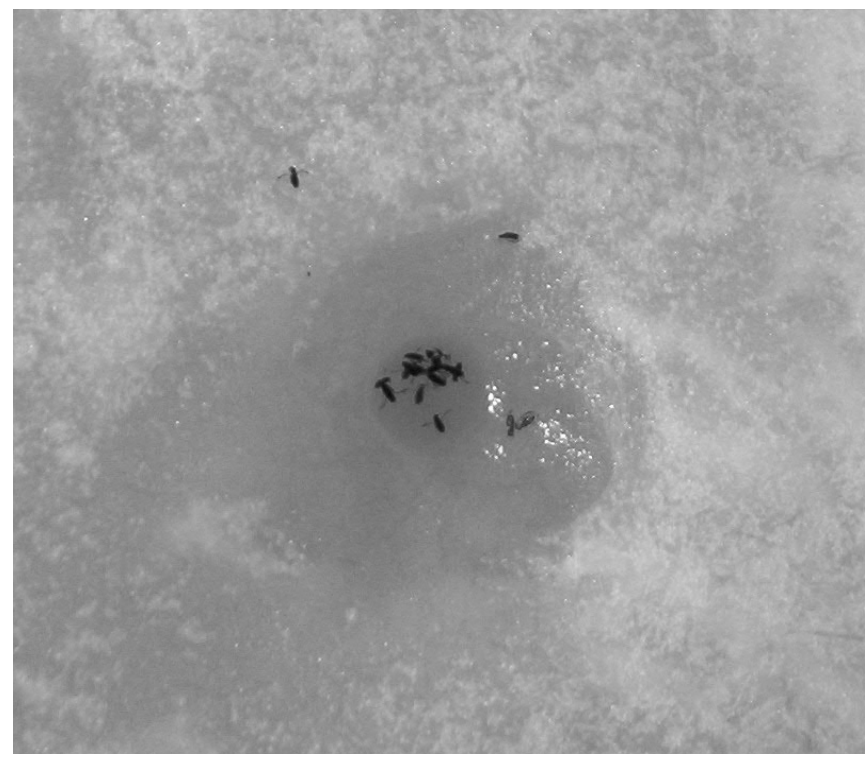

\begin{tabular}{|c|c|c|c|c|c|}
\hline Specimen & Number Alive & Number Dead & Total Number & Survival Rate & Location \\
\hline \multicolumn{6}{|l|}{ Corixidae (Hemiptera) } \\
\hline Cymatia americana & 43 & 11 & 54 & $79.6 \%$ & Deep Ice \\
\hline Callicorixa audeni & o & 1 & 1 & $0 \%$ & Sediment \\
\hline \multicolumn{6}{|l|}{ Notonectidae (Hemiptera) } \\
\hline Notonecta undulata & o & 1 & 1 & $0 \%$ & Deep Ice \\
\hline \multicolumn{6}{|l|}{ Haliplidae (Coleoptera) } \\
\hline Haliplus sp. & 1 & 1 & 2 & $50 \%$ & Sediment \\
\hline \multicolumn{6}{|l|}{ Ceratopogonidae (Diptera) } \\
\hline Bezzia/Palpomyia sp. & o & 4 & 4 & $0 \%$ & Sediment \\
\hline Chironomidae (Diptera) & 29 & 63 & 92 & $31.5 \%$ & Sediment \\
\hline \multicolumn{6}{|l|}{ Coenagrionidae (Zygoptera) } \\
\hline Enallagma/Coenagrion sp. & 0 & 10 & 10 & $0 \%$ & Deep Ice \\
\hline
\end{tabular}




\section{Discussion}

There was little diversity of insects found overwintering within the ice of the pond. Many aquatic insects emerge before the onset of winter; some overwinter in sheltered areas, while others mate, lay their eggs, and perish (Tones, 1977; Moore and Lee, 1991). Those that do not emerge may move into deeper waters to avoid ice, especially in rivers (Olsson, 1983). Sawchyn (1971) described the tendency of damselfly naiads to migrate to deeper waters and aggregate in submerged vegetation during ice formation in ponds. Snow cover may also be important for insulation from winter air temperatures; however, this was not examined in the present study. Despite the low species diversity, a reasonably large number of insects were extracted from the ice and frozen sediment.

\section{Chironomidae}

Past studies have shown a range of survival rates for frozen chironomids in sediment from 25\% (Irons et al., 1993) to $>90 \%$ (Olsson, 1981). The survival rate observed in this experiment was within the lower portion of this range (31.5\%). This may be due to the nature of the sample as it was taken from a fairly shallow region of the pond; this area would likely be the first to freeze down and into the benthic sediments. If freezing occurs within a short period of time, the survival probability of aquatic insect taxa drops (Frisbie and Lee, 1997). Many of the chironomids found in this study were enveloped in cocoons. Danks (2004) suggests that these cocoons may offer protection against freezing temperatures and the physical stress imposed by ice formation.

\section{Corixidae}

The Corixidae, or water boatmen, are common throughout the prairie provinces of Canada and inhabit all bodies of water except the extremely saline (Brooks and Kelton, 1967). There are few studies concerning corixids in the Canadian provinces (e.g. Tones, 1977), and even fewer on the overwintering habits of corixids. The corixids in the present study were mostly found in clusters and surrounded by bubbles encased in the ice. These bubbles may have prevented the formation of ice on and around the corixids' bodies and legs, possibly to mitigate the risk of losing limbs and penetration of the exoskeleton by ice crystals. Since there are fine hairs covering the bodies of corixids that are able to trap air when they submerge, grouping together likely causes the air to form bubbles during ice formation. This clustering behavior may confer another advantage: because corixids are dark on their dorsal surface, concentrated pockets of them would absorb heat from sunlight in the spring, initiating quicker thawing and subsequent liberation of the insects. No literature on corixids grouping in ice was found. However, Maher has seen these clusters in several ponds that he studies around the St. Denis National Wildlife Area in Saskatchewan, Canada and has witnessed corixid assemblages melting faster than the surrounding ice in the spring (personal communication; Figure 2). The survival rate for $C$. americana was the highest among the insects found in this experiment. It was also interesting that $C$. americana was the only species of corixid present in the ice. It is not known if other corixid species were overwintering in the ice. One $C$. audeni was found dead in the sediment, although the decomposed condition of the body suggested that the individual had perished before being frozen. Published literature proposes that corixids, like some other aquatic insects, actively avoid ice formation by moving to deeper waters or migrating to other water bodies (Irons et al., 1993; Danks, 2007a). The literature does not, however, describe corixids overwintering encased in ice.

\section{Other Taxa}

The other specimens retrieved from the ice and sediment samples did not have very high survival rates, although the number of specimens was low (Table 1). Haliplus larvae had a 50\% survival rate, which was confounded by collection of only two specimens. Four ceratopogonid larvae were found and none of them revived after warming. There is evidence, however, that ceratopogonid larvae can survive being frozen in marginal pond sediments (Wiggins et al., 1980 in Drake, 2010). Previous studies (Duffy and Liston, 1985; Moore and Lee, 1991; Irons et al., 1993) have found that damselfly naiads (Zygoptera) can survive being encased in ice over the winter. In particular, Sawchyn (1971) observed this in prairie potholes around Saskatoon, Saskatchewan near the site of this study. However, none of the damselfly naiads were alive in the present study. Each of the 10 naiads retrieved were soft and collapsed once removed from the water. These individuals were likely subjected to internal freezing, causing the tissues to be macerated. One Notonecta undulata was found and did not respond to warming.

\section{Implications and Future Studies}

The implications of studying overwintering in aquatic insects are broad as it is still a poorly explored area of research. The manufacturing and combinations of cryoprotectants used by aquatic insects are still largely unknown, and it is assumed that they share many similarities with their terrestrial counterparts (Duffy and Liston, 1985; Block, 1991; Irons et al., 1993; Danks, 2004, 2006; Lencioni, 2004; Doucet, 2009). Ice nucleators, small particles or microorganisms that initiate ice crystal 
formation, have been suggested as a possible means of terrestrial pest control by applying them to areas where the insects may be overwintering, causing high rates of mortality from internal freezing (Lee et al., 1993; Lundheim, 2002). Studies of inorganic ice nucleators in aquatic insects have found that they are less effective because of the surrounding water (Frisbie and Lee, 1997). Thus, the control of the aquatic larvae of pests such as mosquitoes and blackflies should be studied using microorganisms as ice nucleators. Knowing whether a particular aquatic insect is freeze-tolerant or freeze-intolerant may allow for better management of pest populations while encouraging the development of beneficial species such as damselflies and dragonflies. Danks (1992) suggests that the diversity and life cycles of aquatic insects in Canada should be studied in conjunction with weather patterns. Many overwintering insects are susceptible to temperature changes and the length of diapause can be measured, providing valuable information on changes due to climate change. Further research on the aquatic insects in the prairie region of Canada is needed to determine how species overwinter.

\section{Conclusion}

Researchers have questioned the overwintering habits of insects for many years. While progress has been made among terrestrial insects, overwintering in aquatic insects remains a poorly researched field. This study has revealed the diversity of aquatic insects that overwinter in a prairie pond in Saskatchewan. Corixids were found overwintering encased in ice and displayed high rates of survival upon thawing. Previous literature does not appear to contain much information on corixids overwintering in ice or their grouping habits.

Other aspects of this study are concurrent with previous research, especially in regards to the Chironomidae, their behavioural patterns, and their survival rates. Future studies should investigate several different ponds and compare the diversity, behaviour, ecology, and physiology of insects to those found in other aquatic systems. Implications for such research include improved pest management strategies, further understanding of the impacts of climate change, and improved cold storage of tissues.

\section{Acknowledgments}

I would like to thank Prof. Dennis Lehmkuhl for his continued support, patience, and sharing of his vast knowledge of aquatic insects during this project. I would also like to thank Allen Maher for providing me with photographs from his study site and sharing information with me regarding corixids. 


\section{References}

Arrignon, F., Deconchat, M., Sarthou, J. P., Balent, G., and Monteil, C. (2007). Modelling the overwintering strategy of a beneficial insect in a heterogeneous landscape using a multi-agent system. Ecol. Model. 205: $423-436$

Block, W. (1991). To freeze or not to freeze? Invertebrate survival of sub-zero temperatures. Funct. Ecol. 5: 284-290.

Brooks, A. R. and Kelton, L. A. (1967). Aquatic and Semiaquatic Heteroptera of Alberta, Saskatchewan, and Manitoba (Hemiptera). Mem. Entomol. Soc. Can. 51: 1-92.

Daborn, R. 1971. Survival and mortality of coenagrionid nymphs (Odonata: Zygoptera) from the ice of an aestival pond. Can. J. Zoolog. 49: 569-571.

Danks, H. V. (1992). Arctic insects as indicators of environmental change. Arctic 45: 159-166.

Danks, H. V. (2004). The roles of insect cocoons in cold conditions. Eur. J. Entomol. 101: 433-437.

Danks, H. V. (2005). Key themes in the study of seasonal adaptations in insects I. Patterns of cold hardiness. Appl. Entomol. Zool. 40: 199-211.

Danks, H. V. (2006). Insect adaptations to cold and changing environments. Can. Entomol. 138: 1-23.

Danks, H. V. (2007a). How aquatic insects live in cold climates. Can. Entomol. 139: 443-471.

Danks, H. V. (2007b). The elements of seasonal adaptations in insects. Can. Entomol. 139:1-44.

Danks, H. V. Aquatic insect adaptations to winter cold and ice. In Lancaster, J. and Briers, R. A. (Eds.) Aquatic Insects: Challenges to Populations (pp 1-19) Trowbridge, UK: Cromwell Press.

Doucet, D., Walker, V. K., and Qin, W. (2009). The bugs that came in from the cold: molecular adaptations to low temperatures in insects. Cell. Mol. Life Sci. 66: 1404-1418.

Drake, M. (2010). The importance of temporary waters for Diptera (true flies). In Freshwater forum 17: 26-39.
Duffy, W. G. and Liston, C. R. (1985). Survival following exposure to subzero temperatures and respiration in cold acclimatized larvae of Enallagma boreale (Odonata: Zygoptera). Freshwater Invertebr. Biol. 4: 1-7.

Frisbie, M. P. and Lee, R. E. Jr. (1997). Inoculative freezing and the problem of winter survival for freshwater macroinvertebrates. J. N. Am. Benthol. Soc. 16: $635-650$.

Government of Canada. (2013). Historical climate data for Saskatoon, Saskatchewan, Canada. Retrieved from http://climate.weather.gc.ca

Irons, J. G., Miller, L. K., and Oswood, M. W. (1993). Ecological adaptations of aquatic macroinvertebrates to overwintering in interior Alaska (U.S.A.) subarctic streams. Can. J. Zoolog. 71: 98-108.

Lee Jr, R. E., Lee, M. R., and Strong-Gunderson, J. M. (1993). Insect cold-hardiness and ice nucleating active microorganisms including their potential use for biological control. J. Insect Physiol. 39: 1-12.

Lencioni, V. (2004). Survival strategies of freshwater insects in cold environments. J. Limnol. 63: 45-55.

Lundheim, R. (2002). Physiological and ecological significance of biological ice nucleators. Philos. $T$. R. Soc. B. 357: 937-943.

Merritt, R. W., Cummins, K. W., and Berg, M. B. (eds). (2008). An Introduction to the Aquatic Insects of North America (4th ed.). Kendall/Hunt Publ. Co., Dubuque, IA $1158 \mathrm{pp}$.

Moore, M. V. and Lee, R. E. Jr. (1991). Surviving the big chill: Overwintering strategies of aquatic and terrestrial insects. Am. Entomol. 37: 111-118.

Nagell, B. (1977). Survival of Cloeon dipterum (Ephemeroptera) larvae under anoxic conditions in winter. Oikos, 29: 161-165.

Olsson, T. I. (1981). Overwintering of benthic macroinvertebrates in ice and frozen sediment in a north Swedish river. Holarctic Ecol. 4: 161-166.

Olsson, T. I. (1983). Seasonal variation in the lateral distribution of mayfly nymphs in a boreal river. Holarctic Ecol. 6: 333-339. 
Salt, R. W. (1961). Principles of insect cold-hardiness. Annu. Rev. Entomol. 6: 65-74.

Sawchyn, W. W. (1971). Environmental controls in the seasonal succession and synchronization of development in some pond species of damselflies (Odonata: Zygoptera). (PhD thesis). University of Saskatchewan, Saskatoon, SK.

Sinclair, B. J., Vernon, P., Klok, C. J., and Chown, S. L. (2003). Insects at low temperatures: an ecological perspective. Trends Ecol. Evol. 18: 257-262.

Strathdee, A. T. and Bale, J. S. (1998). Life on the edge: Insect ecology in arctic environments. Annu. Rev. Entomol. 43: 85-106.

Tones, P. (1977). The life cycle of Trichocorixa verticalis interiores Sailer (Hemiptera, Corixidae) with special reference to diapause. Freshwater Biol. 7: 31-3 
